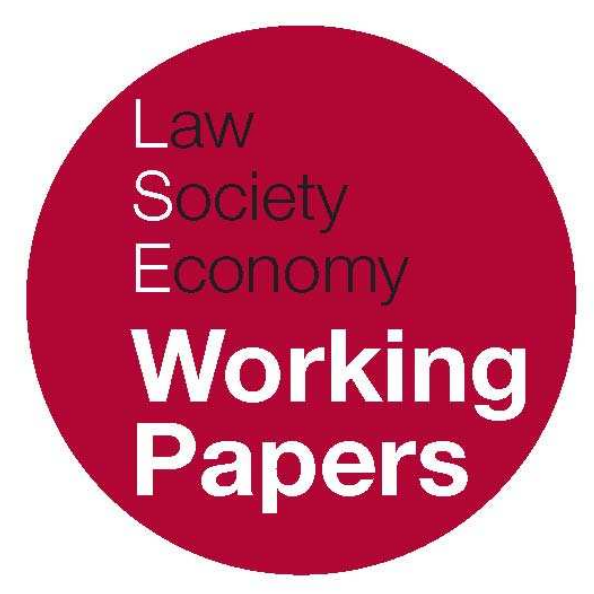

\title{
Between the Devil and the Deep Blue Sea: Administrative Law in an Age of Rights
}

\author{
Thomas Poole
}

LSE Law, Society and Economy Working Papers 9/2008

London School of Economics and Political Science

Law Department

This paper can be downloaded without charge from LSE Law, Society and Economy Working Papers at: www.lse.ac.uk/collections/law/wps/wps.htm and the Social Sciences Research Network electronic library at: http://ssrn.com/abstract=1153631.

(C) Thomas Poole. Users may download and/or print one copy to facilitate their private study or for non-commercial research. Users may not engage in further distribution of this material or use it for any profit-making activities or any other form of commercial gain. 


\title{
Between the Devil and the Deep Blue Sea: Administrative Law in an Age of Rights
}

\author{
Thomas Poole*
}

\begin{abstract}
This paper reflects on the impact of the new jurisprudence of rights on administrative law. It does so by examining two approaches: that adopted by the English courts since 1998, and that followed by Australian courts over roughly the same period. The Australian response has been to sideline human rights and foreign developments relating to them. Rules are preferred to principles, and strict textual exegesis is prized above contextsensitive adjudication. The analysis of English developments presents a contrasting picture of courts almost awash on a sea of principles. Pre-existing rules have been partially abandoned or downgraded. Principles have sprung up in their place and courts have opened themselves up to international law and the decisions of foreign courts. The paper argues that we are far from seeing the realisation of a normatively unified 'common law of judicial review' anticipated by some. Normative heterogeneity within a shared but relatively loose juridical framework in part produced by trasnational dialogues is a more likely future for common law jurisdictions.
\end{abstract}

\section{INTRODUCTION}

Administrative law seems perpetually bedevilled by crises of legitimacy, a predicament no doubt reflecting its suspended position between politics and law, facts and norms. The subject faces a new crisis of identity in the current era, the main source of which is the post-Second World War growth of human rights, that new 'lingua franca of global moral thought'. ${ }^{1}$ The new discourse of rights, itself rooted in notions of law and legality, has had

* Law Department, London School of Economics. The final version of this paper will appear in Linda Pearson, Michael Taggart and Carol Harlow (eds), Administrative Law in a Changing State: Essays in Honour of Mark. Aronson (Oxford: Hart Publishing, 2008).

${ }^{1}$ M. Ignatieff, Human Rights as Politics and Idolatory (Princeton University Press, 2001) 53. 
profound effects on law and legal systems. Two dimensions of this new jurisprudence of rights are particularly pertinent. The first relates to the normativity of rights. Rights (and the laws designed to protect them) claim to have a direct moral content in a way that is not always true of other legal norms. Rights also claim superior status to other standards, values and interests. In particular, they are supposed to act as 'trumps' over countervailing considerations of 'policy'. ${ }^{2}$ Indeed, they would be worthless if they never acted in this way, as Bentham was quick to point out. ${ }^{3}$ This attribute gives rights jurisprudence an imperial - opponents might say necrotising - tendency when situated within a legal order.

The second dimension concerns the universal quality (or at least pretensions) of rights. Rights drive an international discourse the objective of which is to infiltrate and influence the national. ${ }^{4}$ The success of this project means that national orders can no longer be agnostic about rights. But the new jurisprudence of rights does not only operate 'vertically', cascading downwards, that is, from the international to the national. It also operates 'horizontally' - between and across nation states - and at this level courts are important actors. ${ }^{5}$ Legal material relating to rights is now often 'traded' between jurisdictions in which (similar) rights receptive structures operate, a process that has been mapped in terms of transnational juridical 'conversations' or 'dialogues'. ${ }^{6}$ The interpenetration of national and international, and the 'levelling up' effect that this process often entails, ${ }^{7}$ are not unprecedented - the history of the common law, for instance, can be told at least in part a story of transnational legal exchange. ${ }^{8}$ But the normativity of rights - and their potential to transform existing legal

\footnotetext{
2 R. Dworkin, Taking Rights Seriously (Duckworth, 1977).

${ }^{3} \mathrm{~J}$. Bentham, 'Anarchical Fallacies' in J. Waldron (ed.), Nonsense Upon Stilts: Bentham, Burke, and Marx on the Rights of Man (Routledge, 1987).

4 A.W.B. Simpson, Human Rights and the End of Empire: Britain and the Genesis of the European Convention (Oxford: Oxford University Press, 2001).

${ }^{5}$ K. Knop, 'Here and There: International Law in Domestic Courts' (2000) 32 New York University Journal of International Law and Politics 501.

${ }^{6}$ C. McCrudden, 'A Common Law of Human Rights? Transnational Judicial Conversations on Constitutional Rights' (2000) 20 OJLS 499. Cf the idea of judicial globalization: A-M Slaughter, 'Judicial Globalization' (2000) 40 Virginia Journal of International Law 1102; Justice L'Heureux-Dubé, 'The Importance of Dialogue: Globalization and the International Impact of the Rehnquist Court' (1998) 34 Tulsa Law Journal 15.

${ }^{7}$ The recent series of cases (and judicial commentary) on anti-terrorism provides a good example of the 'ratcheting up' effect of this trade in rights jurisprudence: see, e.g., T. Poole, 'Harnessing the Power of the Past? Lord Hoffmann and the Belmarsh Detainees Case' (2005) 32 JLS 534.

8 See, e.g., H.P. Glenn, On Common Laws (Oxford: Oxford University Press, 2005). See also Lauren Benton, Law and Colonial Cultures: Legal Regimes in World History, 1400-1900 (Cambridge: Cambridge University Press, 2002).
} 
arrangements - means that the new pattern of intercourse is qualitatively (as well as quantitatively) different from earlier examples. ${ }^{?}$

This paper reflects on the impact of this new jurisprudence of rights on administrative law (particularly judicial review) by examining two approaches: that adopted by the English courts since 1998, and that followed by the Australian courts over roughly the same period. It presents, then, a comparative study in which the jurisprudence of one system is set against that of another and salient differences articulated and explained. There are dangers in adopting this method, but I hope that the insights that can be derived from the analysis outweigh its flaws.

To foreshadow the argument to come, one response - exemplified by Australia - has been to reject (or at best half-heartedly embrace) the international discourse of rights. In the period of our study, Australian courts have retreated, after the perceived excesses of the Mason Court, to the apparent safe haven of old-fashioned Dixonian legalism. This approach sidelines human rights and foreign developments relating to them. Rules are preferred to principles, and strict textual exegesis is prized above contextsensitive adjudication. The jurisprudence that ensues tends to be conservative, arid and soulless. A second response - typified by the English courts - presents a radically different picture of courts almost awash on a sea of principles. Pre-existing rules, which once acted as - far from perfect - constraints on judicial power, have been partially abandoned or at least downgraded. Principles have sprung up in their place, and these are now clearly infused with moral content. Courts, by no means systematically supine in their decision-making, have opened themselves up to international law and the decisions of foreign courts. All this has resulted in a complicated stew in which the new principles have not been given anything close to coherent shape. In particular, the courts have not been able to find coherent limiting devices to replace those inherent in the old rules thus raising the spectre of 'judicial lawlessness' long feared by critics of judicial review. ${ }^{10}$

\footnotetext{
9 See also, e.g., the debate on 'global administrative law': B. Kingsbury, N. Krisch and R. Stewart, 'The Emergence of Global Administrative Law' (2005) 15 Law \& Contemporary Problems 15.

${ }^{10}$ J.A.G. Griffith, 'Administrative Discretion and the Courts - the Better Part of Valour?' (1955) 18 MLR 159, 163.
} 


\section{THE CONSTITUTIONALISATION OF ADMINISTRATIVE LAW}

But, before turning to the cases, we must take a closer look at the relationship between administrative law and the new international jurisprudence of rights. Dyzenhaus, Hunt and Taggart present this development in terms of the constitutionalisation and internationalisation of administrative law (by which they mean, largely, judicial review). ${ }^{11}$ Central to this process is the formation of a general 'principle of legality'. The principle imposes 'both a duty on administrative decision-makers to give reasons for their decisions and a duty on judges to defer to those reasons to the extent that they refrain from reviewing on a correctness standard', and functions 'as a constitutional principle, one that will in a sense constitutionalise administrative law.' Comparing cases in New Zealand, Australia, Canada and England, they argue that this new 'constitutionalised' judicial review calls for a 'different methodology' the aim of which is to instil a 'culture of justification' within government and public administration. 'The notion of justification, as distinct from explanation, implies that the reasons supporting a decision be "good" reasons, and this in turn requires norms or rules for determining what counts as a "good reason". ${ }^{12}$ The substantive turn in judicial review undermines any preexisting 'hard-and-fast distinction between process and substance' and generates a process of 'constitutional balancing' in which rights are weighed against the reasons offered in defence of governmental action that might be said to infringe them. International law also has an increased role within this new administrative law, since international legal norms both offer a 'good steer' as to the nature of the values that underpin the culture of justification and provide a 'powerful legitimating force'.

The article, although an important contribution, is undertheorised in key respects. I will focus on the twin notions, central to the authors' thesis, of 'internationalisation' and 'constitutionalisation'. Take the latter notion first. The authors clearly intend the term 'constitutionalisation' to include the principle by which governmental powers 'should be exercised in accordance with human rights norms', a principle which generates (inter alia) a general duty to give reasons for decisions (as part of a broader 'culture of justification') and the methodology of 'constitutional balancing'. But,

11 D. Dyzenhaus, M. Hunt and M. Taggart, 'The Principle of Legality in Administrative Law: Internationalisation and Constitutionalisation' (2001) 1 Oxford University Commonwealth Law Journal 5.

12 See also D. Dyzenhaus, 'The Politics of Deference: Judicial Review and Democracy' in M. Taggart (ed.), The Province of Administrative Law (Hart, 1997); M. Hunt, 'Reshaping Constitutionalism' in J. Morison, K. McEvoy and G. Anthony (eds), Judges, Transition and Human Rights (Oxford, 2007). 
beyond general remarks about the influence of international human rights law and references to a sprinkling of domestic cases, we are given little indication of the precise source or nature of the new 'constitutionalised' principles, or how these principles were inscribed into the systems of administrative law in question. (Indeed, it is questionable that the new principles have in all cases taken hold in the way the authors suggest. The inclusion of the Australian case of Teob ${ }^{13}$ - the only Australian case adduced in the article - seems decidedly shaky now, particularly in light of High Court dicta in Lam. ${ }^{14}$ ) Nor is there any real discussion of the relationship between the 'old' tests (legality, procedural fairness, unreasonableness and their like) and the 'new' principles of 'harder edged legality' and 'constitutional balancing'.

The misreading of Teoh, while unfortunate, is also revealing. In focusing exclusively on (certain) developments in the case law, the authors arguably overstate the influence of the courts. Recent experience indicates that it usually takes more than a handful of court cases to effectuate a radical restructuring of a system of administrative law. Writing before the introduction of the Human Rights Act, Freedland argued that the weakness of English judicial review stemmed not so much from the administrative law principles the courts applied, but from the paucity and flaccidity of the constitutional principles which surrounded them. 'It is difficult', he wrote, 'for a tight or rigorous body of administrative law to function effectively in the context of a loose, largely convention-based, system of constitutional law.' ${ }^{15}$ At the time Freedland wrote this, the English courts had started to signal a new, more positive attitude to human rights in cases like Bugdaycay, ${ }^{16}$ Witham $^{17}$ and Smith. ${ }^{18}$ But these developments, despite the bluster of some commentators, ${ }^{19}$ were hesitating and peripheral. Only the passing of the HRA engendered the kind of structural change proponents of rights were seeking. ${ }^{20}$ One main reason for this is that in passing the Act, Parliament authoritatively signalled that significant constitutional and legal changes were both necessary and desirable. Counterfactuals are always problematic,

13 Minister for Immigration and Ethnic Affairs v Teob (1995) 183 CLR 273.

${ }^{14}$ Re Minister for Immigration and Multicultural Affairs, Ex parte Lam (2003) 195 ALR 502.

15 M. Freedland, 'Government by Contract and Public Law' [1994] PL 86, 95.

${ }_{16} \mathrm{R} v$ Secretary of State for the Home Department, exp Bugdaycay [1987] 1 AC 514.

${ }^{17} \mathrm{R} v$ Lord Chancellor, exp Witham [1998] QB 575.

${ }_{18} \mathrm{R} v$ Ministry of Defence, exp Smith [1996] QB 517.

${ }^{19}$ For analysis and criticism of these 'common law constitutionalists', see T. Poole, 'Questioning Common Law Constitutionalism’ (2005) 25 Legal Studies 142.

${ }^{20}$ See, e.g., J. Jowell, 'Beyond the Rule of Law: Towards Constitutional Judicial Review' [2000] PL 671. 
but it seems highly unlikely that anything quite as systematic would have occurred but for the passing of the Act. ${ }^{21}$

The common law thesis - the idea that courts have been the main drivers behind changes in judicial review and that they are creating new principles which operate in very similar ways - also descends into wishful thinking in its other key dimension: the notion of 'internationalisation'. Dyzenhaus, Hunt and Taggart seem to imagine the existence (actual or predicted) of something like a unified system of public law principles that apply across the common law world. One of the authors, indeed, has conceptualised this development in terms of a move towards 'unity' in common law regimes of public law. ${ }^{22}$ Dyzenhaus argues that the new 'common law of judicial review' involves 'a judicial updating of the common law's stock of values to include human rights', the articulation of which is not confined to domestic legal instruments. The 'human rights era' has produced, he says, a system in which judges see themselves primarily as 'guardians of the values that sustain the relationship between individual and state, in which the individual is understood as the bearer of human rights.' 23 This 'tale of the evolution of the common law of judicial review' is not just the result of changes in judicial outlook, but also a question of conceptual design. Dyzenhaus suggests, more specifically, that the separation of powers should be reconceived not as a formal principle of institutional separation but as 'the realisation of, in Kantian terms, a republican ideal', a process that entails in its application that 'violations of the rule of law are to be determined by looking at the substantive values that the separation of powers are supposed to protect rather than to whether the particular arrangement of powers in a legal order has been disturbed.'24

Dyzenhaus is right to draw attention to the growth of transnational legal regimes and the importance of human rights networks. And, without

${ }^{21}$ I suspect that much the same might be said about developments in Canada and New Zealand. See, e.g., G. Cartier, 'The Baker Effect: A New Interface Between the Canadian Charter of Rights and Freedoms and Administrative Law - The Case of Discretion' in D. Dyzenhaus (ed.), The Unity of Public Law (Oxford: Hart, 2004).

22 D. Dyzenhaus, 'Baker: The Unity of Public Law?' in ibid.

${ }^{23}$ D. Dyzenhaus, 'The Rule of (Administrative) Law in International Law' (2005) 68 Law \& Contemporary Problems 127, 139.

24 ibid, 151-2. For a similar account see J. McLean, 'Problems of Translation - The State in Domestic and International Public Law and Beyond', in H. Charlesworth, M. Chiam, D. Hovell and G. Williams (eds), The Fluid State: International Law and National Legal Systems (Sydney: Federation Press, 2005) 216: 'Developments in administrative law in the British Commonwealth have enhanced its permeability to international norms. Administrative law's interest in maintaining the consistency and integrity of executive undertakings in whichever space they are made, combined with its search for unified fundamental values, makes it likely to be influenced by international law processes and norms. There is a coincidence of common law values and the permeability of administrative law to both.' 
question, judges are significant players within these new regimes. (Harlow refers, indeed, to the rise of a 'powerful transnational juristocracy'. $\left.{ }^{25}\right)$ It is (just) possible to imagine with Dyzenhaus a (common law) world - which certainly does not exist at present - in which similar general principles of administrative law have application. But would even this situation entail juridical 'unity'? The nature of administrative law would seem to resist such an eventuality. Administrative law is a subject peculiarly sensitive to, even dependent on, political and administrative context. As Harlow observes, 'administrative law functions within the framework of an accepted political system and constitution, to both of which it is very closely linked.'26 This situation clearly does not preclude connections - even quite systematic connections - and interactions across systems. As common lawyers, we are long accustomed to seeing decisions and approaches in one country being discussed and applied, often in modified form, in another. And scholars have begun to focus on the more general phenomenon of 'transplantation' or 'borrowing' of public law principles. ${ }^{27}$ But, as Taggart (writing in a different context) recognises: 'One of the unavoidable hazards of comparative common law conversations on public law topics ... is that the public law of each common law country can differ markedly because of different conditions and doctrinal development in each country.'28

Even assuming that we see even more systematic 'borrowing' in future years, then, there is no reason to suppose that this will yield the sort of normatively coherent and unified jurisprudence that Dyzenhaus appears to envisage. Fischer-Lescano and Teubner, criticising similar calls for global unity among international lawyers, argue that the search for unified global laws is futile. Starting from Luhmann's prediction that global law would experience a radical fragmentation not along territorial, but along social sectoral lines, ${ }^{29}$ the authors argue that we inhabit a world marked by 'polycentric globalization', ${ }^{30}$ the main driver behind which is 'an accelerated differentiation of society into autonomous social systems, each of which

25 C. Harlow, 'Global Administrative Law: The Quest for Principles and Values' (2006) 17 EJIL 187, 209.

26 ibid, 208.

${ }^{27}$ For an exploration of this theme, see S. Choudhry (ed.), The Migration of Constitutional Ideas (Cambridge: Cambridge University Press, 2007). Processes of interaction are often complicated and can have significant effects on the 'donor' state as well as the recipient. Principles from one system, for instance, are sometimes applied in others and then 'fed back with a difference' to the donor state. See, e.g., J. Polakiewicz and V. Jacob-Foltzer, 'The ECHR in Domestic Law: The Impact of the Strasbourg Case-Law in States where Direct Effect is Given to the Convention' (1991) 12 Human Rights LJ 125.

${ }_{28}$ M. Taggart, 'The Tub of Public Law', in The Unity of Public Law, n 21 above, 461-2.

${ }^{29}$ N. Luhmann, 'Die Weltgesellschaft' (1971) 57 Archiv für Rechts und Sozialphilosophie 21.

${ }^{30}$ D. Held, Democracy and the Global Order: From the Modern State to Cosmopolitan Governance (Cambridge: Polity Press, 1995), 62. 
springs territorial confines and constitutes itself globally.' 31 The process results in the creation of 'global villages', relationships between which 'are anything but harmonious.' The problems of global society arise in large measure from the clash of rationalities that ensues, which is 'caused by the fragmented and operationally closed functional systems of a global society, which, in their expansionist fervor, create the real problems of global society, and who at the same time make use of global law in order normatively to secure their own highly refined sphere logics. ${ }^{32}$ It is highly unlikely, given the complexity of the situation produced by these processes of legal evolution and social differentiation, that law can ever play a 'strong' coordinating role. We must give up the idea that the unity of global law should be 'structure-based' - that is, institutionally secured normative consistency - and proceed from the idea that it is process-based - that is, 'deriving simply from the modes of connection between legal operations, which transfer binding legality between even highly heterogenous legal orders.'33 The 'solution' (or response) to fragmentation, then, is not (normative) unity - which is probably impossible - but a functional pluralism within which the "best law can offer ... is to act as a "gentle civilizer of social systems". 34

The development of a 'common law of judicial review' grounded in human rights - if that is really what we are seeing - is not likely to produce anything like a normatively unified jurisprudence. We can expect more by way of transnational interaction between lawyers and courts, more crossborder judicial conversations, networking and the like. To be sure, this process may sometimes result in (perhaps partial) convergence, as principles - like proportionality? - and doctrines - like deference? - are taken up by one system and passed on to the next. Landmark decisions will resonate in far-flung places. (But, then again, when have they not?) But when this sort of thing does occur, we should not simply assume that the reception of such principles and doctrines will be the same everywhere. Administrative law is entwined with constitutional law, as Freedland noted, and everywhere dependent on local conditions, particularly the structure of politics and public administration. These characteristics militate against the realisation of a normatively unified common law of judicial review. Normative heterogeneity within a shared but relatively loose juridical framework in part produced by transnational dialogues is a more plausible scenario than

31 A. Fischer-Lescano and G. Teubner, 'Regime Collisions: The Vain Search for Legal Unity in the Fragmentation of Global Law' (2004) 25 Michigan Journal of International Law 999, 1006.

32 ibid, 1007.

33 ibid, 1007-8

34 ibid, 1045. 
homogeneity of administrative law principle. If this is the case, then we should reject the 'common law of administrative law thesis', at least in its stronger formulations, and start thinking instead of the genesis of a 'quilt of legalities'35 in which functionally independent common law jurisdictions interact within a partly-shared language and normative framework.

\section{THE DEVIL: AUSTRALIA}

A 'devotion to legalism', Goldsworthy says, is the default position of Australian courts. Rooted 'in British legal traditions imbibed by Australian lawyers educated in the late $19^{\text {th }}$ and early $20^{\text {th }}$ centuries', Australian judges have evinced a general 'tendency to prefer formal, abstract, and conceptual analysis, to substantive factual or evaluative reasoning'. ${ }^{36}$ The early Engineers' case affirmed that English-style literalist and formalist interpretation was the order of the day. The Court's duty was 'faithfully to expound and give effect to [the Constitution] according to its own terms, finding the intention from the words of the compact, and upholding it throughout precisely as framed'. ${ }^{37}$ But the canonical statement of this orthodoxy was provided by Sir Owen Dixon - still a totemic figure among Australian lawyers - who argued that the only safe guide to judicial decision-making is 'a strict and complete legalism'. 38 While this approach no doubt reflected the political and legal conservatism of the judges, it is worth noting that formalism, while methodologically conservative, need not necessarily result in judicial inaction. ${ }^{39}$ The High Court has sometimes acted in an 'active formalist'40 way - that is, deploying traditional legal categories, for instance, in the defence of minority or vulnerable groups - the classic illustration being the Communist Party case. ${ }^{41}$

\footnotetext{
35 B. de Sousa Santos, Toward a New Legal Common Sense (Oxford: Butterworths, 2002) 163.

${ }^{36} \mathrm{~J}$. Goldsworthy, 'Australia: Devotion to Legalism' in J. Goldsworthy (ed.), Interpreting Constitutions: A Comparative Study (Oxford: Oxford University Press, 2006) 155 \& 133.

37 Amalgamated Society of Engineers v Adelaide Steamship Co Ltd [1920] HCA 54; (1920) 28 CLR 129, 142. See also Attorney General (NSW) v Brewery Employees Union of NSW (1908) 6 CLR 469 where it was held that the words of the Constitution, unless formally amended, continue to mean what they meant in 1900.

38 Sir O. Dixon, 'Two Constitutions Compared' in Dixon, Jesting Pilate (Sydney: The Law Book Company, 1965) 247.

39 For a general analysis of the phenomenon, see J. Shklar, Legalism (Cambridge MA: Harvard University Press, 1964).

${ }^{40}$ C. Harlow and R. Rawlings, Law and Administration (London: Butterworths, $2^{\text {nd }}$ ed, 1997) 516.

41 Australian Communist Party v Commonwealth (1951) 83 CLR 1 (where the High Court invalidated legislation that proscribed the Communist Party and affiliated organizations, confiscated their
} 
The Mason Court, 'without doubt an agent of change', ${ }^{42}$ broke from this Dixonian orthodoxy. ${ }^{43}$ 'It is generally agreed that in the late 1980s, the Court took a new direction, adopting a more purposive and even creative approach in constitutional and other cases.' ${ }^{44}$ This change in method produced (or coincided with) a series of innovative decisions in cases such as Mabo, ${ }^{45}$ Dietrich, ${ }^{46}$ Teoh, ${ }^{47}$ Wik, $^{48}$ ACTV ${ }^{49}$ and Leeth. ${ }^{50}$ While it may be an overstatement to talk about these cases marking a rupture with the past, the decision-making at this time certainly constituted a move away from formalism and a greater degree of openness about the Court's law-making role. ${ }^{51}$ Sir Anthony Mason himself openly rejected Dixonian legalism, arguing that the traditional approach 'conceals rather than reveals the reasoning process' of the court. ${ }^{52} \mathrm{He}$ adopted instead a 'species of legal realism' according to which judges in top courts must in appropriate cases make choices. These choices, he said, are inevitably influenced by 'policy factors and values' and should be discussed as such by the courts. ${ }^{53}$ The search to identify (and justify) the choice of factors and values on which these landmark cases were decided led the Court to look more frequently to international law, and even on occasion to invoke the idea of an evolving 'global' common law. Australian judges were increasingly influenced in this era by the global trend of expanding judicial power to protect rights. As Brennan $\mathrm{J}$ observed in his judgment in Mabo, international law is a legitimate and important influence on the development of the common law'. ${ }^{4}$

property without compensation, and excluded persons deemed dangerous to national security from certain kinds of employment).

${ }^{42}$ F. Wheeler and J. Williams, "Restrained Activism" in the High Court of Australia' in B. Dickson (ed.), Judicial Activism in Common Law Supreme Courts (Oxford: Oxford University Press, 2007).

${ }^{43}$ See, e.g., M. Detmold, 'The New Constitutional Law' (1994) 16 Sydney LR 228.

44 n 36 above, 144.

45 Mabo v Queensland (No. 2) (1992) 175 CLR 1 (recognition of native title).

46 Dietrich v The Queen (1992) 177 CLR 292 (directed trial courts to use their inherent powers to shield financially needy defendants from an unfair trial).

47 n 13 above.

48 Wik. Peoples v Queensland (1996) 187 CLR 1 (pastoral leases did not necessarily extinguish native title). This decision, however, postdates Sir Anthony Mason's retirement from the Court.

49 Australian Capital Television Pty Ltd v Commonwealth (1992) 177 CLR 106 (recognized implied freedom of communication about political matters).

${ }^{50}$ Leeth v Commonwealth (1992) 174 CLR 455 (in which a majority of the Court entertained the idea that the Constitution required legal equality in some form).

51 J. Doyle, 'Implications of Judicial Law-Making' in C. Saunders (ed.), Courts of Final Jurisdiction: The Mason Court in Australia (Sydney: Federation Press, 1996) 84.

52 Sir A. Mason, 'The Centenary of the High Court of Australia' (2003) 5 Constitutional Law and Policy Review 41, 45.

53 Sir A. Mason, 'Legislative and Judicial Law-Making: Can We Locate an Identifiable Boundary' (2003) 24 Adelaide LR 15, 21.

${ }^{54} \mathrm{n} 45$ above, 42 . 
The practice of the Gleeson Court has seen a reversion to Dixonian method. ${ }^{55}$ Dyson Heydon, a member of that Court, has argued extrajudicially that 'there has been a recalibration of doctrine in key areas suggestive of a desire to check the perceived activism of the Mason era.' Comparing Mason era courts unfavourably with those of Dixon's day, Heydon has criticised 'the role of judicial activism in damaging both the probity of the courts and ... the capacity of the courts to retain a sound grip on the applicable law in particular cases'. ${ }^{56} \mathrm{He}$ is particularly scathing of the Mason Court's tendency to resort to international law, 'international expectations' and the 'international community. ${ }^{57} \mathrm{McHugh} \mathrm{J}$ is another strong advocate of a traditional judicial role: 'The function of the judiciary', he wrote in his judgment in Re Wakim, is to give effect to the intention of the makers of the Constitution as evinced by the terms in which they expressed that intention. ${ }^{5} 8$

But what characteristics might we expect cases decided by a formalist court to exhibit? I suspect that we might expect to see the following:

- an emphasis on rules and the avoidance of principles;

- a tendency to de-contextualise decisions under review;

- adherence to traditional ('strict') canons of statutory construction and the deployment of narrow - often abstruse - legalist reasoning;

- sidelining international law;

- conservatism.

Does this model of formalist decision-making match the reality of decisionmaking in Australian administrative law? The authors of the leading textbook on the subject certainly think so. Describing the dominant current judicial methodology as 'markedly incrementalist', Aronson, Dyer and Groves observe that 'most judicial review judgments are long on the specific rules, but short to a fault on the guiding principles. 59 And, turning to the cases, it is easy to find evidence to support this assessment. Neat Trading v Wheat Export Authority involved a challenge to the respondent's repeated refusal of applications for export consent, a policy pursued in order to protect its monopoly on wheat exports. The question arose

\footnotetext{
55 The intervening Brennan Court era was a period of retrenchment in which innovations from the Mason Court era were respected and protected but fewer progressive decisions were reached.

${ }^{56}$ D. Heydon 'Judicial Activism and the Death of the Rule of Law' (2003) 47 Quadrant 9, 13-14. This address is also published in: (2003) 23 Australian Bar Review 1.

57 ibid, 21.

58 Re Wakim, exp McNally [1999] HCA 27 [35]-[39]; (1999) 198 CLR 511 549-50.

${ }^{99}$ M. Aronson, B. Dyer and M. Groves, Judicial Review of Administrative Action (3rd ed., 2004), 164.
} 
whether the common law prohibited the adoption of a blanket policy in this context. A majority of the High Court rejected the application, holding that the profit-maximising behaviour of the respondent - a private corporation - was incompatible with the existence of public law obligation, at least in this instance. ${ }^{60}$ Not only does this decision present a formalist solution to what has been called the 'Datafin problem'. ${ }^{61}$ (The Court reserved for future consideration the general question of the suitability of the 'sources' test.) It also wraps the decision in a narrow, legalist conception of the role of the court. Although himself prepared to assume that the respondent was susceptible to judicial review - he dismissed the case on its 'administrative law merits' - Gleeson CJ defended this general position with customary astringent elegance:

It is to the provisions of the Act that one must look for some warrant for concluding that a particular consideration is obligatory, or available, or extraneous. Judicial review is not an invitation to judges to decide what they would consider fair or reasonable if they were given the function conferred upon AWBI. The appellant might genuinely believe that the system itself is unfair. A judge might share that opinion. Nothing follows from that. The question is what, if anything, the Act requires, or permits, or forbids, AWBI to take into account in giving effect to its role in the system. ${ }^{62}$

A more recent attempt to grapple with the public/private law divide arose in Griffith University v Tang. ${ }^{63}$ The case involved a challenge from a doctoral student who had been excluded from her programme for allegedly fabricating research results. She argued that she had been denied procedural fairness as a result of the University's failure to follow its own disciplinary procedures. The case was brought under Queensland's Judicial Review Act 1991 - the equivalent of the Commonwealth ADJR Act - which provides (under s.4) for judicial review of 'a decision of an administrative character made ... under an enactment'. Her action failed. The majority - Gummow, Callinan and Heydon JJ - argued, first, that even if the decision could be said to derive from contract or some other private law source it was not a

\footnotetext{
${ }^{60}$ Kirby J dissented on the ground that AWBI's decisions were reviewable since the company was an integral part of the regulatory process and so exercised 'public power'.

${ }^{61} \mathrm{R} v$ Panel on Take-Overs and Mergers, exp Datafin plc [1987] 1 AB 815. On which see, seminally, M. Aronson, 'A Public Lawyer's Response to Privatisation and Outsourcing' in M. Taggart (ed.), The Province of Administrative Law, n 12 above.

62 NEAT Domestic Trading Pty Ltd v AWB Ltd [2003] HCA 35, [20]. n 59 above, 78.

63 [2005] HCA 7; (2005) 221 CLR 99.
} 
decision made 'under an enactment' and so not susceptible to judicial review (Gleeson CJ joined them on this ground); and, second, that a reviewable decision must in any case 'confer, alter or otherwise affect legal rights or obligations' and that the applicant 'had no relevant legal rights' in this case. ${ }^{64}$ The decision has been criticised by commentators on a number of grounds. ${ }^{65}$ For present purposes, the following features of the decision are worth noting: a reiteration of the type of approach discarded in Datafin but followed in NEAT Trading; a narrow construction of the statute against the interests of the complainant; and the addition of requirement that a right sourced in 'hard' law (general law or statute) must be affected before judicial review may be sought - reminiscent, as Taggart points out, ${ }^{66}$ of the pre-Ridge $\mathrm{v}$ Baldwin requirement that a decision-maker had to be acting judicially or quasi-judicially before natural justice could lie. ${ }^{67}$

When we turn to examine the English cases, we will see that there has been a sharp increase in the scope of 'substantive' judicial review. Attention now falls on the proportionality principle and its (bastard?) offspring 'deference'. But even before the decision to recognise the proportionality principle, English courts had been expanding the scope of the otherwise self-limiting $W$ ednesbury test to allow for more intensive review in cases involving 'fundamental' rights. ${ }^{68}$ Australian courts, according to Stern, have indicated a clear reluctance to follow the line of English cases which recognise a right to relief in judicial review proceedings based upon conspicuous unfairness amounting to an abuse of power.' ${ }^{9} 9$ Such an approach, Australian judges reason, runs counter to the principle of separation of powers and the requirement that judicial review under s.75(v) of the Constitution should only be for jurisdictional error. As Gleeson CJ observed in Lam, 'The constitutional jurisdiction does not exist for the purpose of enabling the judicial branch of government to impose upon the executive branch its ideas of good administration. ${ }^{70}$

Whereas English courts have encouraged the broadening and splintering of the unreasonableness test, Australian courts, after flirting briefly with this 'variegated approach', are now 'retreat[ing] to the originally

\footnotetext{
64 [89] \& [96].

65 See, e.g., M. Aronson, 'Private Bodies, Public Power and Soft Law in the High Court' (2007) 35 Federal Law Review; D. Stewart, "Griffith University v Tang, "Under an Enactment" and Limiting Judicial Review’ (2005) 33 Federal Law Review 526.

66 M. Taggart, “'Australian Exceptionalism” in Judicial Review” (2008) 36 Federal Law Review 1.

${ }^{67} \mathrm{R} v$ Electricity Commissioners, ex p London Electricity Joint Committee (1920) Ltd [1924] 1 KB 171; Ridge v Baldwin [1964] AC 40.

${ }^{68} \mathrm{R} v$ Ministry of Defence, exp Smith [1996] QB 517.

${ }^{69}$ K. Stern, 'Substantive Fairness in UK and Australian Law' (2007) 29 Australian Bar Review 266, 266.

${ }^{70}$ Re Minister for Immigration and Multicultural Affairs, exp Lam (2003) 214 CLR 1, [32].
} 
demanding standard' and seeking 'a reduction in the sorts of matters that can be tested by this ground. ${ }^{71}$ Three developments may be adduced as representative of this trend. First, in exp Applicant S20/2002, the High Court held that irrationality (or illogicality) and unreasonableness are mutually exclusive categories and that $W$ ednesbury unreasonableness was limited in scope - it could not be used, for instance, to challenge grossly unreasonable fact-finding. ${ }^{72}$ Second, the refusal by the Federal Court to countenance the Wednesbury test being tightened to allow for heightened scrutiny in cases involving human rights. $^{73}$ Third, the rejection of proportionality as a ground or aspect of review in state courts, ${ }^{74}$ the Federal Court $^{75}$ and (save for the support of Kirby J ${ }^{76}$ ) the High Court. ${ }^{77}$ We see in these examples the same tendency to favour 'traditional' understandings of 'traditional' legal categories, an approach animated by the desire to prevent any expansion of judicial review on the basis of arguments of justice or fairness.

The High Court's rejection of the doctrine of 'deference' offers another example of this traditionalist temperament. Deference is often seen as quid pro quo for more intensive review. In City of Enfield, the High Court addressed the question of whether Australian jurisprudence should recognise something like the Chevron test that operates in American administrative law. ${ }^{78}$ Chevron-style deference applies where the statute administered by a federal agency is susceptible to a number of constructions. If it is, then the reviewing court must defer to an agency's reasonable interpretation of the statute in question. ${ }^{79}$ The High Court rejected the Chevron approach on two grounds: (a) it has undesirable

\footnotetext{
71 Aronson et al., n 59 above, 334.

72 Re Minister for Immigration and Multicultural Affairs; ex p Applicant S20/2002 (2003) 198 ALR 59. Compare the recent judgment of Mumby J in R (SK) v Secretary of State for the Home Department [2008] EWHC 98 (Admin), [2]: 'the melancholy facts that have been exposed as a result of these proceedings are both shocking and scandalous. They are shocking even to those who still live in the shadow of the damning admission by a former Secretary of State that a great Department of State is "unfit for purpose". They are scandalous for what they expose as the seeming inability of that Department to comply not merely with the law but with the very rule of law itself.'

73 SZADC v Minister for Immigration and Multicultural and Indigenous Affairs [2003] FCA 1497, at [24].

${ }^{74}$ See, e.g., Bruce v Cole (1998) 45 NSWLR 163 at 185, where Spigelman CJ held that proportionality was not a ground of review in its own right.

75 Andary v Minister for Immigration and Multicultural Affairs [2003] FCAFC 211 at [12].

${ }_{76}$ Leask v Commonwealth (1996) 187 CLR 579, at 634-636.

77 Aronson et al., n 59 above, $347-8$.

78 Corporation of the City of Enfield v Development Assessment Commission [2000] HCA 5; (2000) 199 CLR 135.

${ }^{79}$ Chevron USA Inc. v Natural Resources Defense Council Inc. 467 US 837 (1984). But see also United States v Mead Corporation 533 US 218 (2001) which narrowed the scope of the Chevron doctrine. For comparative analysis see M.C. Tolley, 'Judicial Review of Agency Interpretation of Statutes: Deference Doctrines in Comparative Perspective' (2003) 31 Policy Studies Journal 421.
} 
consequences in that it might encourage an agency to mould an interpretation of a statute in order to avoid judicial scrutiny; (b) it is inconsistent with the principle that it is for the judicial branch to declare and enforce the law which determines the power conferred by statute upon administrators. ${ }^{80}$ Now, on the face of it, the decision in City of Enfield bucks the quiescent, conservative pattern observed in the cases examined so far. But we should remember, first, that methodological formalism does not necessarily equate to conservative outcomes. (Plaintiff S157, discussed next, provides a clearer example of this.) And, second, that the (re)assertion of an exclusive jurisdiction to interpret statutes is entirely at one with a traditional understanding of the nature of the judicial role. It is form, once again, that counts. ${ }^{81}$

Plaintiff S157/2002 v Commonwealth involved a direct constitutional challenge to a federal privative clause purporting to exclude judicial review of certain kinds of migration decisions. The case concerned the right of the plaintiff to seek judicial review of a decision of the Refugee Review Tribunal affirming a refusal of his protection visa application. The relevant section of the statute defined a 'privative clause decision' as a 'decision of an administrative character made ... under this Act'. ${ }^{82}$ Although the Court did not directly strike down the clause in question, it decided that judicial review still held for jurisdictional error, as a jurisdictionally flawed decision was not properly a decision 'made under' the Act. A jurisdictional error occurs where, reading the Act as a whole, it can be said to involve the breach of an inviolable condition on the exercise of power under the Act. ${ }^{83}$ The decision must be set in the context of an ongoing struggle between the judiciary and government over the power to review executive decisions about migration (particularly concerning asylum seekers). In this particular engagement, the government 'aimed to abolish judicial review of migration decisions as far as is constitutionally possible. ${ }^{84}$ Aronson et al. call the joint

\footnotetext{
${ }^{80}$ City of Enfield, at [42] \& [43]. See also Gaudron J at [60]: 'it is the function of the court, when its jurisdiction is invoked, to determine, for itself, whether the fact or the factual situation does or does not exist. To do less is to abdicate judicial responsibility.' The test was also not immediately applicable on the facts of the case.

${ }^{81}$ Margaret Allars argues that the rejection of Chevron might in any case be 'duplicitous' because of the development of an 'expertise test' in cases like Minister for Aboriginal Affairs v Peko-Wallsend Ltd (1986) 162 CLR 24 and Attorney-General (NSW) v Quin (1990) 170 CLR 1: 'Chevron in Australia: A Duplicitous Rejection?' (2002) 54 Admin LR 569.

82 Migration Act 1958 (Cth) s.474, as amended by Migration Legislation Amendment Act (No. 1) 2001 and Migration Legislation Amendment (Judicial Review) Act 2001.

${ }^{83}$ This test has subsequently been applied liberally by the Federal Court in Lobo v Minister for Immigration and Multiculturalism [2003] FCA 144.

${ }^{84}$ C. Beaton-Wells, 'Australian Administrative Law: The Asylum-Seeker Legacy’ [2005] PL 267.
} 
judgment in $S 157$ 'uncompromising', 85 while Kerr and Williams argue that the decision 'develops rule of law principles in funding that the Constitution provides for an entrenched minimum level of judicial review (based upon the concept of jurisdictional error) for actions by an officer of the Commonwealth. ${ }^{\prime 86}$ Yet this outcome was achieved through characteristically formalist means, presenting an intriguing blend of pragmatism and principle'. ${ }^{87}$ The Court managed to find a way of determining that judicial review remained open for the plaintiff while avoiding the sort of direct confrontation with the legislature and executive that would have resulted had the Court struck down the relevant section in the statute. Like the related decision of the House of Lords in Anisminic, ${ }^{88}$ the High Court in $S 157$ reached its conclusion through a process of what seems like legalistic alchemy. And, like the older English case, one also wonders whether the decision may have been motivated, at least in part, by a sense of amour propre as much as a concern for the development of legal principle.

Whereas City of Enfield and $S 157$ show the High Court, for whatever combination of reasons, in 'active formalist' mode, the last two decisions we address are conservative in every sense. Al-Kateb v Godwin concerned the lawfulness of the possible indefinite detention of a non-citizen who could not be removed from Australia under the Migration Act 1958 (Cth). The predicament in which the detainees found themselves parallels that of the claimants in the Belmarsh Detainees case, ${ }^{89}$ although the Australian case did not concern the operation of anti-terrorism laws. The result, however, was the opposite of that reached by the House of Lords, since the majority in Al-Kateb found that the words of the statute, which required a person's removal from Australia 'as soon as reasonably practical', were unambiguous and 'too clear to read them as being subject to a purposive limitation or an intention not to affect fundamental rights'..$^{90}$ By contrast, the dissenting judges (Glesson CJ, Gummow and Kirby JJ) argued that more explicit language was required to signal an intention to interfere with personal liberty in so drastic a way. ${ }^{91}$ The majority approach exhibits many of the

85 Aronson et al., n 59 above, 849.

${ }^{86}$ D. Kerr and G. Williams, 'Review of Executive Action and the Rule of Law under the Australian Constitution' (2003) 14 Public Law Review 219, 232.

87 ibid, 222.

88 Anisminic Ltd v Foreign Compensation Commission [1969] AC 147.

${ }^{89} A \mathrm{v}$ Secretary of State for the Home Department [2004] UKHL 56.

90 Al-Kateb v Godwin [2004] HC 37 at [33] (McHugh J).

91 ibid, [22] (Gleeson CJ). 
characteristics of the formalist model of decision-making described above. ${ }^{92}$ The case was decided as though stripped from its context (indefinite detention and its impact on personal liberty), through the application of (intolerably?) strict canons of statutory construction. ${ }^{93}$ The Court focussed almost exclusively on Australian law, excluding from consideration both international law and the decisions of foreign courts. McHugh J called the suggestion that the Court should seek conformity with international law to the extent permitted by the statute's language 'a fiction' and described as 'heretical' the view that rights should be read into the Constitution by drawing upon international instruments. ${ }^{94}$ Indeed, it is the combination of what Curtin calls 'ruthless literalism' and 'judicial introspection', 95 both vividly present in the majority decision in Al-Kateb, that is characteristic of the playing out of Dixonian legalism in the current era.

The High Court deployed similar techniques to produce a judgment of almost baroque obscenity in Thomas $\mathrm{v}$ Mowbray. While not strictly speaking an administrative law case, the decision is important and worth examining in terms of the light it sheds on issues central to our analysis. The case concerned a challenge to the imposition of 'interim control orders' under Div. 104 of the Criminal Code (Cth). Thomas had been issued with a control order, after being acquitted of charges relating to terrorism offences, which restricted his movement and ability to communicate with others. ${ }^{96}$ The constitutionality of the control order provision was challenged on two grounds: first, whether the Commonwealth government had the power to legislate in this way, either under its defence or external affairs powers; second, whether the Code confers judicial power in an unconstitutional manner. The Court dismissed the plaintiff's arguments on both these grounds. Gummow and Crennan JJ said, on the first point, that "[p]rotection from a "terrorist act" as defined necessarily engages the defence power. ${ }^{\prime 97}$ This despite the fact that in the Communist Party case the same power was not considered sufficient, at a time when Australia was involved in the Korean War, to support laws disbanding the Communist

\footnotetext{
${ }^{92}$ For analysis of the case see, e.g., B. Saul, 'Australian Administrative Law: The Human Rights Dimension' in M. Groves and H.P. Lee (eds), Australian Administrative Law (Cambridge: Cambridge University Press, 2007).

${ }^{93}$ See D. Meagher, "The "Tragic" High Court Decisions in Al-Kateb and Al Khafaji: the Triumph of the "Plain Fact" Interpretive Approach and Constitutional Form over Substance' (2005) 7 Constitutional Law and Policy Review 69.

94 n 90 above, [63].

${ }^{95}$ J. Curtin, “'Never Say Never”: Al-Katebv Godwin” (2005) 27 Sydney LR 355.

96 See A. Lynch and A. Reilly, 'The Constitutional Validity of Terrorism Orders of Control and Preventative Detention' (2007) 10 Flinders Journal of Law Reform 105.

97 Thomas v Mowbray [2007] HCA 33, [146].
} 
Party. ${ }^{98}$ In rejecting the second argument, which focussed on the legality of a judicial power to restrict a person's liberty on the basis of what the person might do in the future, the Court observed that this is 'in truth a power that has been, and is, exercised by courts in a variety of circumstances' including bail and apprehended violence orders. ${ }^{99}$ There is no trace in Thomas $\mathrm{v}$ Mowbray of the trend in courts elsewhere towards more intensive scrutiny of new anti-terrorism powers. ${ }^{100}$ Kirby J, again in dissent, criticised what he saw as the majority's denigration of the Communist Party case and its 'unfortunate surrender ... to demands for more and more governmental powers ... that exceed or offend the constitutional text and its abiding values.' ${ }^{101}$ In yet another politically sensitive case, the legalist and decontextual approach was used by the Gleeson Court to produce a decision - itself perhaps at odds with actual Dixonian decisions - inimical to the interests of liberty but very much in accordance with the aggrandising instincts of the Howard Administration. ${ }^{102}$

The preceding analysis does not purport to offer a comprehensive survey of Australian administrative law during the period in question. But the cases surveyed do provide some evidence that the reversion to Dixonian legalism, invoked extra-judicially by some members of the present High Court, has been realised. There is certainly a close correlation between the model of formalism offered at the start of this section and the pattern of decision-making observed in the examined cases. The cases exhibit a tendency to emphasise established rules and a concomitant distrust of more wide-ranging principles (like proportionality). They also show the judges engaging in de-contextual decision-making and applying traditional principles of statutory interpretation often in a manner inimical to liberty (and related) interests. This approach tends to be accompanied by a rejection of the influence of international law and, to a lesser extent, the decisions of foreign courts. The conservatism of method adopted in these cases is matched, more often than not, by the conservatism of their

\footnotetext{
98 n 41 above.

${ }^{99}$ n 97 above, [15] (Gleeson CJ).

100 Compare, for instance, Charkaoui v Canada (Citizenship and Immigration), 2007 SCC 9 or the recent control order decisions of the House of Lords: Secretary of State for the Home Department v JJ [2007] UKHL 45; Secretary of State for the Home Department v MB [2007] UKHL 46; Secretary of State for the Home Department v E [2007] UKHL 47. See also the US Supreme Court cases: Rasul v Bush 542 US 466 (2004); Hamdi v Rusmfeld 542 US 507 (2004); Rumsfeld v Padilla 542 US 426 (2004); Hamdan v Rumsfeld 126 S. Ct. 2749 (2006).

101 n 97 above, [385] \& [386].

$102 \mathrm{On}$ the character and impact of the John Howard era see, e.g., P. Kelly, 'Re-thinking Australian Governance: The Howard Legacy' (2006) 65 Australian Journal of Public Administration 7.
} 
outcomes. And all this is wrapped up in a rhetorical approach that seems, to this outsider at least, to be maddeningly abstruse in its legalism.

Indeed, after working through these arcane and endlessly selfreferential judgments, one begins to wonder whether the current High Court is not engaged in a kind of juridical Glass Bead Game rather than the operation of a system of administrative justice. Certainly, the reversion to formalism after a period of anti-formalism at home and during an antiformalist era abroad must amount to something more than a simple return to juridical form. Dixonian legalism today, that is to say, means something different from what it meant in Dixon's time. For it is one thing to embrace legalism as a means of insulating the judges from stormy political weather in formalist times, but to do so at a time when courts elsewhere are moving in a quite different direction is deliberately to court isolation. It amounts, then, to a deliberate rejection both of the 'activist' traits - legal and political - of the Mason Court and the international jurisprudence of rights previously embraced by that Court. ${ }^{103}$ In this environment, the play of legalism becomes almost a parody of legalism. Since, as Taggart observes, the High Court practice of reciting legal 'mantras - perhaps even shibboleths' does not equate to impartial decision-making but simply 'diverts attention from the manipulable nature of the doctrines as applied.' 104 Judges revel in the opaque and obscurantist quality of their judgments. Law becomes ritual. And no-one is remotely convinced that any of it is apolitical.

\section{THE DEEP BLUE SEA: THE UK}

Turning our attention to the UK, we confront a situation very much in flux, the main cause of which is the introduction of the Human Rights Act 1998 ('HRA'). While it is true that 'fundamental' rights had become more established features of the legal landscape during the 1990s, ${ }^{105}$ these developments have been dwarfed by what has happened since. Indeed, it is not necessarily an overstatement to regard the HRA as the catalyst for what may amount to a reformation of English administrative law. ${ }^{106}$ The ongoing nature of these developments, however, makes it hard to distinguish with

\footnotetext{
${ }^{103}$ For a discussion of the latter see H. Charlesworth, M. Chiam, D. Hovell and G. Williams, No Country is an Island: Australia and International Law (UNSW Press, 2006).

104 n 66 above.

105 See, e.g., M. Hunt, Using Human Rights Law in English Courts (Hart, 1998).

106 T. Poole, 'The Reformation of English Administrative Law' (2009) 68 Cambridge Law Journal (forthcoming).
} 
precision the trends that will prove long-lasting from those that will diminish. This being so, I approach the analytical task in a somewhat unorthodox manner in this section, running side by side two plausible readings of (or, perhaps, two cautionary tales relating to) current developments.

Proportionality, now established as a principle of judicial review and carrying the potential perhaps to revolutionize the discipline, will provide the main focus of the inquiry. The proportionality test is said to have four stages. ${ }^{107}$ First, the legislative objective must be sufficiently important to justify limiting a fundamental right; second, the measure designed to meet the objective must be rationally connected to it; third, the means used to impair the right must go no further than is necessary to accomplish the objective; fourth, the balance struck between the rights of the individual and the interests of the community must be acceptable. Proportionality was not recognized by the English courts as a free-standing principle of review before the HRA, ${ }^{108}$ although there were occasional dicta to the effect that one day this situation might change. ${ }^{109}$ It became clear, however, that the introduction of the HRA would change this situation and, in Daly, the House of Lords applied a proportionality approach in holding that there had been a violation of the claimant's right to the confidentiality of his correspondence with legal advisors. ${ }^{110}$ Lord Steyn stated that the proportionality principle, rather than the $W$ ednesbury test or any sub-division of it, should be applied when European Convention on Human Rights (ECHR) rights are at stake. Proportionality was, Lord Steyn said, a 'more precise and more sophisticated' test which allows for a 'somewhat greater' intensity of review than its predecessor. In particular, proportionality 'may require the reviewing court to assess the balance which the decision maker struck' and 'may go further than the traditional grounds of review as it may require attention to be directed to the relative weight to be accorded to interests and considerations. ${ }^{111}$ The decision to adopt proportionality was prompted by the criticism of the European Court of Human Rights which said in Smith and Grady v UK that the Wednesbury test, even in its 'anxious

\footnotetext{
107 See, e.g., Huang v Secretary of State for the Home Department [2007] UKHL 11, [19]; R (Razgar) v Secretary of State for the Home Department [2004] UKHL 27, [20]. See also R v Oakes [1986] 1 SCR 103. Compare de Freitas v Permanent Secretary of the Ministry of Agriculture [1999] 1 AC 69 (where the Privy Council outlined a 3-stage test).

108 R v Secretary of State for the Home Department, ex $p$ Brind [1991] 1 AC 696. English courts were, however, obliged to apply proportionality in the context of EU law: see, e.g., $\mathrm{R} v$ Minister of Agriculture, Fisheries and Food, exp Roberts [1991] 1 CMLR 555.

${ }_{109}$ Council for Civil Service Unions v Minister for the Civil Service [1985] AC 374, 410 (L Diplock).

${ }_{110} \mathrm{R} v \mathrm{~S}$ Secretary of State for the Home Department, exp Daly [2001] UKHL 26.

111 ibid, [27].
} 
scrutiny' manifestation, was inadequate to protect Convention rights. ${ }^{112}$ (The Strasbourg Court judgment, indeed, was referred to at various points in the House of Lords decision. ${ }^{113}$ )

A number of commentators (and judges) see proportionality as a way of reinvigorating judicial review. For these writers, proportionality provides not only a more structured way of negotiating the issue of substantive review than the existing $W$ ednesbury test. ${ }^{114}$ But also, being clearly infused with moral colour, it has the potential to ensure that the relationship between government and governed is effectively policed by the court. ${ }^{115}$ David Beatty's The Ultimate Rule of Law is the most sustained and farreaching elaboration of this position. Proportionality accounts, Beatty says, for 'virtually every case in which courts have responded politically to protect people's general welfare and well being'.116 Rejecting 'prudential arguments' that call for courts to defer to agency expertise, he argues for the full-blown and unencumbered application of the proportionality principle by the courts. That principle, he claims, provides the 'only conceptual apparatus judges have, and all that they need, to harmonize the autonomy of each person with the general will of the community'. ${ }^{117}$ 'External' - non rights-based - elements should be shut out from judicial consideration. 'Rather than evaluate the competing interests at stake against some external, objective standard or principle, judges try to assess the affected parties' own understanding of how significant the law being tested is for them.' 118

While many of us might share Beatty's verdict that proportionality marks a normative advance on Wednesbury and welcome, with Lord Steyn, the ability of that principle openly to allow for more intensive review in some instances, we should pause to consider the wider implications of its adoption, at least in the undiluted manner envisaged by Beatty. Even on Lord Steyn's (naturally rather cautious) formulation, it is clear that we are talking about a test that is open-ended and potentially very intrusive indeed. In applying proportionality, courts are required, we are told, 'to assess the balance which the decision maker struck' and to pay attention 'to the

\footnotetext{
112 Smith and Grady v United Kingdom (1999) 29 EHRR 493; Lustig-Pream and Beckett v United Kingdom (1999) 29 EHRR 548.

113 n 110 above, [27] (L Steyn) \& [32]: 'But the view that the standards [of proportionality and Wednesbury] are substantially the same appears to have reached its quietus in Smith and Grady' (L Cooke).

114 See, e.g., J. Jowell and A. Lester, 'Beyond Wednesbury: Substantive Principles of Administrative Law' [1987] PL 368.

115 See, e.g., Jowell, n 20 above.

116 D. Beatty, The Ultimate Rule of Law (Oxford: Oxford University Press, 2004) 144.

117 ibid, 116.

118 ibid, 93.
} 
relative weight to be accorded to interests and considerations'. This could mean that courts in effect retake - and to do so quite openly - agency decisions. (And to do so without consideration of the identity of the agency, since on Beatty's formulation it seems not to matter for whether the thing in question is a decision of a low-level official or an Act of Parliament.) This development, in which authority and legitimacy questions other than those directly related to rights would be stripped from the process of review, amounts to a very radical reworking of judicial review, at least as it is currently understood by its participants. And unlike Wednesbury, which contains within it a self-limiting warning or reminder of the limits of the judicial role, nothing in the proportionality test indicates when intensive scrutiny might not be appropriate. The proportionality principle contains very little of substance, save for the general notion that decisions should not be disproportionate, and so gives no real indication of how it ought to be applied. As Adler observes, for all its rational pretensions, it is at least arguable that proportionality is 'primarily non-rational since it depends upon whether we believe that the sacrifice of the individual interest is too great a burden.' 119

One way of responding to the dangers of proportionality - its illdefined scope and potentially limitless reach - has been to concentrate on the idea of deference as a limiting device. Hunt, indeed, sees the development of deference doctrines as the flip-side of the 'unequivocal embrace' of proportionality by the courts. ${ }^{120}$ Although he doubts the value of 'spatial language of areas or margins of discretion', Hunt argues that a 'rich conception of legality and the rule of law' should accord 'a role for the democratic branches in the definition and furtherance of fundamental values. ${ }^{121}$ Laws LJ has advanced the most systematic attempt in practice to fashion a framework for the calibration of deference. In the International Transport case, Laws LJ specified four principles for determining the level of deference owed by a court to a public authority. First, more deference should be shown an Act of Parliament than to a subordinate measure or executive decision. Second, there is more scope for deference 'where the Convention itself requires a balance to be struck, much less so where the right is stated in terms which are unqualified'. Third, greater deference is

119 J. Adler, 'The Sublime and the Beautiful: Incommensurability and Human Rights' [2006] PL 697, 699.

${ }^{120}$ M. Hunt, 'Sovereignty's Blight: Why Contemporary Public Law Needs the Concept of "Due Deference"" in N. Bamforth and P. Leyland (eds), Public Law in a Multi-Layered Constitution (Hart, 2003) 340-1.

121 ibid, 339 \& 350. See also, e.g., D. Dyzenhaus, 'The Politics of Deference: Judicial Review and Democracy' in M. Taggart (ed.), The Province of Administrative Law, n 12 above. 
owed where the subject-matter is within the constitutional responsibility of the decision-maker, and less when it lies within the constitutional responsibility of the courts. Fourth, the degree of deference also depends on whether the subject-matter lies within the expertise of the decisionmaker or the court. ${ }^{122}$

But the attempt to find principles of deference that might provide some structure and limit to the application of the proportionality test has been criticised. Like Beatty, T.R.S. Allan deplores the new doctrines of judicial deference which he regards as nothing more than 'non-justiciability dressed in pastel colours. ${ }^{123}$ Deference, for Allan, is either an empty or a pernicious doctrine. It is empty if it 'purports to implement a separation of powers between the courts and other branches of government', since such a separation is secured by 'the proper application of legal principles defining he scope of individual rights'. It is pernicious if 'it permits the abdication of judicial responsibility in favour of reliance on the good faith or good sense or special expertise of public officials, whose judgments about the implications of rights in specific cases may well be wrong. ${ }^{124}$ Considerations not directly related to the right in question - for instance, those that relate to 'characteristics of the decision-maker or its procedures' - are classified as 'external considerations' inappropriate for judicial consideration.

The courts have yet to have worked out quite how the 'tangled story'125 of deference is to be resolved. But one reading of (some of the) recent doctrinal developments would fit the position articulated by 'hardliners' like Beatty and Allan. Let us call this reading, since it is really a vision of the future of administrative law, the noble dream. On this reading, proportionality takes its rightful place at the centre of a newly minted 'constitutionalised' body of administrative law. (For, as Taggart puts it, why wander through maze of administrative law when you can cruise the motorway of constitutional law?) And, in this system, courts recognise that proportionality works in a different way and cuts deeper into agency discretion than any previous principle or rule. They apply it, then, without recourse to inappropriate doctrines, like deference, which serve to qualify the rights-centred quality of the new legal framework. And, since now 'the only proper question for the court to consider is simply whether or not the

122 International Transport Roth GmbH v Secretary of State for the Home Department [2002] EWCA Civ 158; [2003] QB 728, at [81]-[87].

123 T.R.S. Allan, 'Human Rights and Judicial Review: A Critique of "Due Deference"” (2006) 65 CLJ 671,682 .

124 ibid, 675.

125 L. Steyn, 'Deference: A Tangled Story' [2005] PL 346. 
decision falls within the sphere of decision-making autonomy that the claimant's right, on its correct interpretation, allows', ${ }^{126}$ the court should now be unconcerned with the identity of the agency or its behaviour in the process of decision-forming - even, for instance, if the agency has come to its own conclusions about the rights-related dimensions of the issue in question.

There is some support for this reading in the cases. Some of this support focuses on the terminology of 'deference', which is disliked by some members of the judiciary. Lord Hoffmann, in particular, while recognising the "current popularity of the word "deference" to describe the relationship between courts and other political bodies', has said that he does not find 'its overtones of servility, or perhaps gracious concession, are appropriate to describe what is happening' in the cases. ${ }^{127}$ Likewise, in their recent Report in Huang, the House of Lords opined that the weighing of competing factors was not 'aptly described as deference' but rather the 'performance of the ordinary judicial task of weighing up the competing considerations on each side and according appropriate weight to the judgment of a person with responsibility for a given subject matter and access to special sources of knowledge and advice.'128 There is also some support for the hardliners' rejection of the relevance to the judicial consideration of an agency's own understanding of the rights interests at stake. Lord Hoffmann recently argued in the Miss Behavin' case that the court should disregard any 'display of human rights learning' on the agency's part. ${ }^{129}$

But there are reasons to expect that the courts will stop themselves from sleepwalking, as it were, into the 'noble dream'. Shorn of principles of deference, or for that matter any other limiting device, proportionality provides little more than a capacious - indeed, rapacious - tool (or rationalist mask?) for the ungoverned expansion of judicial review. As Taggart says, proportionality 'has not been adequately normatively justified and inevitably will entail inadequately restrained or disciplined judicial discretion.' At least as conceived by hardliners like Beatty and Allan, the application of the test 'requires placing too much faith in the judges to do the right thing.' ${ }^{130}$ The enormous increase in judicial discretion that this position entails is the opposite of the rational, structured approach to review that Lord Steyn in Daly and earlier advocates of proportionality had

\footnotetext{
$126 \mathrm{n} 123$ above, 671-2.

127 R (ProLife Alliance) v British Broadcasting Corporation [2004] 1 AC 185, at [75].

128 Huang v Home Secretary, above n. 107, [16].

129 Belfast City Councilv Miss Behavin' Ltd [2007] UKHL 19, [13].

${ }^{130}$ M. Taggart, 'Proportionality, Deference, Wednesbury' (unpublished paper), 42.
} 
in mind. What we encounter, instead, is the prospect of courts floundering on an apparently limitless ocean of principle. Thus, we find Laws LJ in Abdi - himself no mean advocate of rights-based judicial review ${ }^{131}$ - engaged in a frankly 'bizarre' 132 process of casting around for a principle on which to ground a conclusion already reached by other (non-specified) means.

I would so conclude on the simple ground that the merits of the Secretary of State's case press harder than the appellant's, given the way the points on either side were respectively developed by counsel. ... But I find it very unsatisfactory to leave the case there. The conclusion is not merely simple, but simplistic. It is little distance from a purely subjective adjudication. ... Accordingly a public body's promise or practice as to future conduct may only be denied, and thus the standard I have expressed may only be departed from, in circumstances where to do so is the public body's legal duty, or is otherwise, to use a now familiar vocabulary, a proportionate response (of which the court is the judge, or the last judge) having regard to a legitimate aim pursued by the public body in the public interest. The principle that good administration requires public authorities to be held to their promises would be undermined if the law did not insist that any failure or refusal to comply is objectively justified as a proportionate measure in the circumstances. ${ }^{133}$

We should be thankful for Laws LJ for making this full disclosure of his reasoning process. For it reveals the reality of judging under the influence of the noble dream. A decision based upon an assessment of the arguments presented by counsel, and/or judicial instinct, propped up ex post - almost laughably - on the vague invocation of even vaguer principles. And, besides the fashionable rhetorical flourish - the same passage also includes

\footnotetext{
131 See, e.g., Sir J. Laws, 'The Constitution: Morals and Rights' [1996] PL 622.

${ }^{132}$ T. Hickman, 'The Structure and Content of Proportionality' [2008] PL (forthcoming).

133 Abdi v Secretary of State for the Home Department [2005] EWCA Civ 1363, 67-68. Another excellent example is provided by the recent decision of the House of Lords in $R$ (Animal Defenders International) v Secretary of State for Culture, Media and Sport [2008] UKHL 15. The case involved a challenge to a decision by the Broadcast Advertising Clearance Centre that ADI's proposed advertisement (part of its 'My mate's a primate' campaign) was a political advertisement and that therefore it could not be broadcast in the television or radio media. The application was dismissed, but not before their Lordships had waxed lyrical about freedom of expression being an essential condition of both 'an intellectually healthy society' and 'truly democratic government' (L Bingham, at [27]). Baroness Hale said that the case was 'not just about permissible restrictions on freedom of expression' but also 'about striking the right balance between the two most important components of a democracy: freedom of expression and voter equality' (at [49]). While studiously avoiding the language of deference, the case seemed finally to turn on the (rather old-fashioned?) notion that, in this context, the 'judgment of Parliament ... should no be lightly overridden' (L Bingham at [33]).
} 
references to 'the call to arms of abuse of power' and 'the moral impetus of the rule of law' - the principled approach contains nothing capable either of grounding or making sense of the 'Objective justification' means nothing without an articulation of the standards by which we may judge the justificatory reasons. 'Proportionate' means nothing since, as we have seen, the notion of proportionality has very little normative content. And the idea of 'legitimate aim' tells us nothing about what counts as legitimate decisionmaking. The principled patina is just as simple (or should that be simplistic?) as the original, unreasoned decision.

The second reading - or cautionary tale - is rather more plausible than a scenario in which the judges allow judicial review to collapse into unstructured normativism. I will call this alternative account the formalist nightmare. Instead of the genesis of a new normative jurisprudence in which rights and proportionality have free rein, that is to say, courts may tend to react by introducing or reverting to formalist tests and concepts that feel either familiar or otherwise 'safe' in a new juridical world that is inherently difficult to navigate. One such attempt occurred in the Court of Appeal decision in the Denbigh High School case, the most important case on proportionality since Daly. There, Brooke LJ argued that since the school authorities had not applied a full-scale proportionality analysis to its decision to exclude a Muslim schoolgirl who wished to wear a jilbab in contravention of the school's uniform policy, ${ }^{134}$ for that reason the application should succeed. 'The School did not approach the matter in this way at all. Nobody who considered the issues on its behalf started from the premise that the claimant had a right which is recognised by English law, and that the onus lay on the School to justify its interference with that right'. ${ }^{135}$ This approach was (rightly) scotched by the House of Lords, where Lord Bingham said that it "would introduce "a new formalism" and be "a recipe for judicialisation on an unprecedented scale".'136 But other formalist solutions have been more favourably received. The House of Lords seem to

\footnotetext{
134 R (SB) v Headteacher and Governors of Denbigh High School [2005] EWCA Civ 199, at [75]: according to Brooke LJ, the structure of process of decision-making should have taken the following line: 'Has the claimant established that she has a relevant Convention right which qualified for protection under Art. 9(1)? (2) Subject to any justification that is established under Art. 9(2), has that Convention right been violated? (3) Was the interference with her Convention right prescribed by law in the Convention sense of that expression? (4) Did the interference have a legitimate aim? (5) What are the considerations that need to be balanced against each other when determining whether the interference was necessary in a democratic society for the purpose of achieving that aim? (6) Was the interference justified under Art. 9(2)?'.

135 ibid, at [76]. For critical analysis of this decision, see T. Poole, 'Of headscarves and heresies: the Denbigh High School case and public authority decision-making under the Human Rights Act' [2005] PL 685.

${ }^{136} \mathrm{R}$ (Begum) v Headteacher and Governors of Denbigh High School [2006] UKHL 15, [31].
} 
have decided to tether their analysis of Convention rights to the jurisprudence of the European Court of Human Rights. ${ }^{137}$ This manoeuvre, rather like tying the peso to the dollar, is attractive for a court seeking to shore up its legitimacy in turbulent times. But there is no requirement to do this in the HRA - s. 2 speaks about the need to 'take into account' Strasbourg cases when interpreting Convention rights. And it is normatively entirely unjustified. The Strasbourg Court recognizes its special position as a supranational court - hence its 'margin of appreciation' doctrine. As well as assuming (wrongly ${ }^{138}$ ) that that Court is normatively infallible, this approach entails that English judges do not have to consider for themselves the importance of the right at stake nor the legitimacy of certain types of interference, yet surely these matters are of the essence in rights-based adjudication.

Similar stirrings of this 'new formalism' are present outside the immediate context of rights and proportionality. What we see operating currently, taking a broad perspective, is a bifurcated system in which 'ordinary' and 'rights-based' judicial review operate in different ways. In terms of substantive review, Wednesbury unreasonableness remains the test for the former; proportionality now governs the latter. ${ }^{139}$ The standing rules are different for both. ${ }^{140}$ 'Sufficiency of interest' (as interpreted, often generously, by the courts ${ }^{141}$ ) governs the 'ordinary' process, while those seeking to bring claims under the HRA must be 'victims' of the decision in question. ${ }^{142}$ The system that results is messy and (overly?) complicated. It also undercuts the claim that a principled framework of judicial review is now being created. This situation is at least partly a function of the partial abandonment of old formulae and pre-existing rules. A trend seems to be emerging in which new principles and ideas are embraced, and older ideas denigrated or curtailed, but not entirely repudiated. The interplay of proportionality and Wednesbury again offers the best example. The comments of Dyson LJ in the Association of British Civilian Interests case to the effect that it would not be long before someone stepped up to perform the

137 Huang v Home Secretary, above n. 107; Secretary of State for Defence v Al-Skeini [2007] UKHL 58, [106]; R (Ullah) v Special Adjudicator [2004] UKHL 26, [20]; R (Animal Defenders International) v Secretary of State for Culture, Media and Sport [2008] UKHL 15, [53].

138 See, e.g., M-B Dembour, Who Believes in Human Rights? Reflections on the European Convention (Cambridge: Cambridge University Press, 2006).

139 R v Chief Constable of Sussex, ex p International Trader's Ferry Ltd [1999] 2 AC 418 (where both proportionality and Wednesbury were applied). For analysis see M. Elliott, 'The Human Rights Act 1998 and the Standard of Substantive Review' [2002] Judicial Review 97.

140 J. Miles, 'Standing under the Human Rights Act 1998: Theories of Rights Enforcement and the Nature of Public Law Adjudication' (2000) CLJ 133.

${ }^{141}$ C. Harlow, 'Public Law and Popular Justice' (2002) 65 MLR 1.

142 HRA s. 7. 
burial rites for Wednesbury - but not us, not now - are typical. ${ }^{143}$ This pattern discloses a generalised uncertainty about how to articulate the new framework of judicial review. Unconvinced by the grandiose schemes of the 'hardliners' and worried about the far-reaching impact of the decision to adopt proportionality, the courts seem often unwilling to let go of older nostrums and incapable, it would appear, of establishing new ones - or at least ones in which they might fully believe.

So the survey of developments in the English context also ends on a sour note. Two conflicting, but related, accounts (or cautionary tales) have been canvassed. The first - the 'noble dream' - which builds on the idea that the unfettered application of the proportionality principle should form the centrepiece of the 'new' administrative law, undoubtedly encourages and supports the normative turn in judicial review. But it raises the prospect of what might be called an 'unprincipled principled' approach, one which leaves the courts adrift on a sea of largely unstructured judicial discretion. ${ }^{144}$ The second - the 'formalist nightmare' - may occur where judges, in trying to escape the noble dream, or otherwise unsure of how to direct administrative law into the future, cling to both old and newly minted formalisms, and in so doing create a messy and complicated system which undercuts the claims of principle.

\section{CONCLUSION}

The survey of Australian and English developments contained within this paper has shown two remarkably different approaches to the spread of the new 'jurisprudence of rights'. While by no means comprehensive, the analysis of the decision-making of the Gleeson Court reveals a position

\footnotetext{
143 The Association of British Civilian Interests - Far Eastern Division v Secretary of State for Defence [2003] EWCA Civ 473, [34] \& [35].

144 Another excellent example is provided by the recent decision of the House of Lords in Animal Defenders International, n 137 above. The case involved a challenge to a decision by the Broadcast Advertising Clearance Centre that ADI's proposed advertisement (part of its 'My mate's a primate' campaign) was a political advertisement and that therefore it could not be broadcast in the television or radio media. The application was dismissed, but not before their Lordships had waxed lyrical about freedom of expression being an essential condition of both 'an intellectually healthy society' and 'truly democratic government' (L Bingham, at [27]). Baroness Hale said that the case was 'not just about permissible restrictions on freedom of expression' but also 'about striking the right balance between the two most important components of a democracy: freedom of expression and voter equality' (at [49]). While studiously avoiding the language of deference, the case seemed finally to turn on the (rather old-fashioned?) notion that, on this issue, the 'judgment of Parliament ... should no be lightly overridden' (L Bingham at [33]).
} 
antagonistic towards both the language of human rights and the international and transnational discourse in which that language is most commonly located. The Court, deliberately turning its back on the methodology of its predecessor, has ostensibly reverted to Dixonian 'strict and complete legalism'. But this reversion has led to what amounts almost to a parody of legalism, in which members of the Court seem almost to revel in an esoteric and abstract formalism that produces, at least on occasion, judgments almost barbaric in their lack of concern for either context or moral outcomes.

Developments in England during the same period present a sharply contrasting picture. The embrace of rights - particularly as a result of the passing of the HRA - and the adoption of the proportionality test have created a situation of great flux, within which some voices call for a much more thoroughgoing 'righting' of administrative law. This approach, advocated most strongly by Beatty and Allan, locates proportionality firmly at the centre of a reconstructed administrative law - Beatty apparently sees no need for any other principle - and would remove what is currently the court's principal limiting device, the idea of 'deference'. But, rights being inherently indeterminate and the proportionality test being open-ended and without limit, buying into this 'noble dream' would leave courts adrift on a ocean of principle. There is a danger, however, that in seeking to avoid this particular danger, the courts may fall into another: the 'formalist nightmare'. They may start - and this has already happened in some cases - to revert to older traditions of formalism, devising doctrines which may provide limits but do so without good cause.

It might just be possible to present these findings in terms of an overarching linear narrative about rights and administrative law. On this account, English jurisprudence is currently in the process of 'working itself pure', on the verge of merging into the general pattern of a (relatively 'thick') transnational common law of judicial review. And the Australian position, while currently exceptional, might one day resume the path to juridical righteousness. But a more plausible account would be to understand these jurisdictions, historically both linked and independent, as two participants within a relatively 'thin' common juridical framework - two islands, if you prefer, within a broader juridical archipelago. ${ }^{145}$

145 Cf C. Kukathas, The Liberal Archipelago: A Theory of Diversity and Freedom (Oxford: Oxford University Press, 2003). 